\title{
A new Myxococcus xanthus gene cluster for the biosynthesis of the antibiotic saframycin Mx1 encoding a peptide synthetase
}

\author{
Andreas Pospiech, Bernard Cluzel, Jürg Bietenhader and \\ Thomas Schupp
}

Author for correspondence: Thomas Schupp. Tel: +4161 6965051. Fax: +41616969301.

Ciba-Geigy AG,

Biotechnology Research, K-681 .346, CH-4002 Basel, Switzerland

\begin{abstract}
The gene cluster for the biosynthesis of the heterocyclic quinone antibiotic saframycin Mx1 of Myxococcus xanthus DM504/15 was inactivated and tagged by Tn5 insertions. The tagged genes were cloned in Escherichia colf and used to select overlapping cosmid clones spanning $58 \mathrm{~kb}$ of the $M$. xanthus genome. Gene disruption experiments defined a $\geqslant 18 \mathrm{~kb}$ contiguous DNA region involved in saframycin biosynthesis. Sequencing of part of this region revealed a large ORF containing two 600-amino-acid domains with similarity to peptide synthetase amino-acid-activating sequences, suggesting that saframycin Mx1 is synthesized by a nonribosomal multienzyme complex, similar to other bioactive peptides.
\end{abstract}

Keywords: Myxococcus xantbus, saframycin Mx1, antibiotic, peptide synthetase

\section{INTRODUCTION}

Saframycins belong to the group of heterocyclic quinone antibiotics including mitomycins and streptonigrin (Nakatsubo et al.,1977; Weinred et al., 1982) which bind covalently to DNA and inhibit cellular DNA and RNA synthesis (Ishiguro et al., 1978, 1981; Kishi et al., 1984; Lown et al., 1982). Saframycins A, B, C, D and E were isolated first from Streptomyces lavendulae (A rai et al., 1977, 1980). Saframycin $\mathrm{Mx} 1$ is produced by the $\mathrm{Gram}$-negative myxobacterium Myxococcus xantbus (Irschick et al., 1988). Saframycins have antimicrobial (Irschick et al., 1988) and good antitumour activity (A rai et al., 1980; Kishi et al., 1984). Fig. 1 shows the structure of saframycin Mx1 (Trowitzsch-Kienast et al., 1988). The dimeric N-heterocyclic quinone which is present in all saframycins is derived from two tyrosine molecules and the side chains are derived from glycine and alanine (Mikami et al., 1985).

The myxobacteria grow in soil and have a complex life cycle with multicellular differentiation. Similar to differentiating actinomyctes and bacilli, they produce a large number of secondary metabolites (Reichenbach, 1986; Reichenbach et al., 1988). The knowledge of genes involved in the synthesis of myxobacterial secondary metabolites is however still limited to two gene clusters

Abbreviation: CIAP, calf intestine alkaline phosphatase.

The GenBank accession number for the sequence reported in this paper is U24657. involved in the biosynthesis of the macrolide antibiotics TA (myxovirescin A) from M. xanthus (Gerth et al., 1982; Tolchinsky et al., 1992; Varon et al., 1992) and the soraphen A gene cluster of Sorangium cellulosum. Genes for

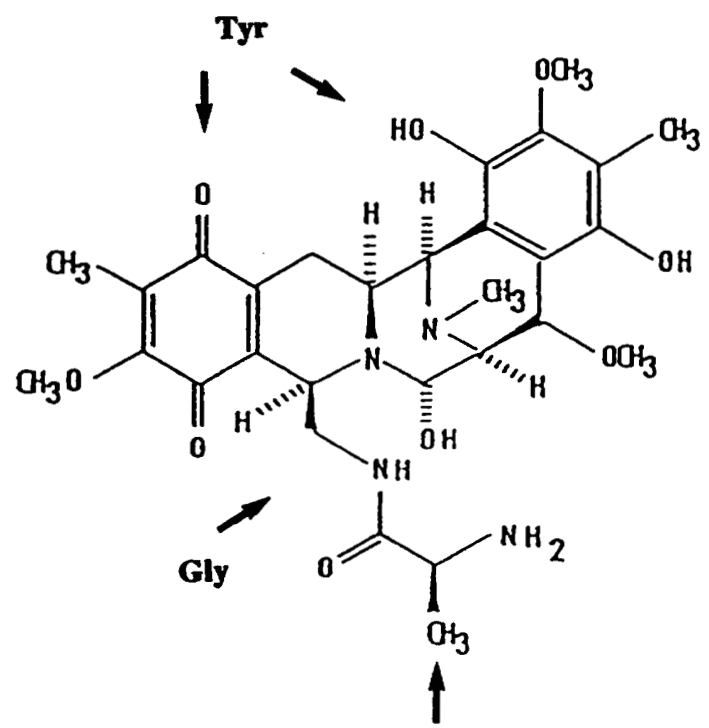

Ala

Fig. 1. Structure of saframycin Mx1 derived from alanine, two tyrosines and glycine. 
the latter have been cloned and sequenced, revealing repetitive type I polyketide synthetases (Schupp et al., 1995; Hopwood \& Khosla, 1992).

Here we report the cloning in Escherichia coli of $58 \mathrm{~kb}$ contiguous $M$. xanthus DNA involved in the biosynthesis of saframycin Mx1. Transposon mutagenesis and gene disruption by homologous recombination in $M$. xantbus were used to define $a \geqslant 18 \mathrm{~kb}$ DNA region involved in antibiotic production, and sequencing of part of this region revealed similarities to peptide synthetases, consistent with the biosynthetic origin of saframycin $\mathrm{Mx} 1$.

\section{METHODS}

Bacterial strains and plasmids. These are listed in Table 1. For gene disruption experiments the conjugative plasmids pSUP202 and pCIB132 were used. For DNA sequencing, fragments were cloned in pBluescript II SK(+).

Media and culture conditions. E. coli was grown at $37^{\circ} \mathrm{C}$ in Luria broth (LB) or on LB agar. Sarcina lutea was grown at $30^{\circ} \mathrm{C}$ on solid DST medium (Oxoid) or in liquid BHI medium (BBL). $M$. xanthus was grown at $28^{\circ} \mathrm{C}$ in $\mathrm{S} 45$ medium $(3 \mathrm{~g}$ casein peptone $\mathrm{l}^{-1}, 2 \mathrm{~g} \mathrm{MgSO}_{4} .7 \mathrm{H}_{2} \mathrm{Ol}^{-1}, 0.5 \mathrm{~g} \mathrm{CaCl}_{2} .2 \mathrm{H}_{2} \mathrm{Ol}^{-1}, 1 \cdot 2 \%$, $\mathrm{w} / \mathrm{v}, \mathrm{HEPES}, \mathrm{pH} 7 \cdot 2$ ), or on solid S46 medium (S45 with $12 \mathrm{~g}$ agar $\left.\mathrm{l}^{-1}\right)$. Antibiotics were used at the following concentrations

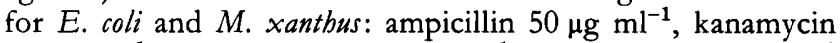
$50 \mu \mathrm{g} \mathrm{ml} l^{-1}$, streptomycin $100 \mu \mathrm{g} \mathrm{ml}^{-1}$, tetracycline $10 \mu \mathrm{g} \mathrm{ml}^{-1}$ and chloramphenicol $34 \mu \mathrm{g} \mathrm{ml}^{-1}$.

Tn5 mutagenesis of $M$. xanthus DM504/15. An overnight culture of E. coli S17-1 containing pSUP2021 and grown under kanamycin, ampicillin and chloamphenicol selection was diluted 100 -fold with LB medium without antibiotics and incubated for a further $6 \mathrm{~h}$. Subsequently $1 \times 10^{10}$ cells of this $E$. coli culture and $5 \times 10^{8}$ cells of $M$. xanthus DM504/15 (grown at $28^{\circ} \mathrm{C}$ to a cell density of $2 \times 10^{8} \mathrm{ml}^{-1}$ and preincubated for $10 \mathrm{~min}$ at $45^{\circ} \mathrm{C}$ ) were mixed, sedimented $(8000 \mathrm{~g}, 3 \mathrm{~min})$, resuspended in $150 \mu \mathrm{l}$ S45 medium and spotted onto S46 agar without antibiotics. After overnight incubation at $28^{\circ} \mathrm{C}$, cells were scraped off the agar and resuspended in $1 \mathrm{ml} \mathrm{S} 45$ medium. Portions $(100 \mu \mathrm{l})$ were plated onto $\mathrm{S} 46$ plates containing $100 \mu \mathrm{g}$ streptomycin $\mathrm{ml}^{-1}$ (streptomycin resistance encoded by $\operatorname{Tn} 5$ is expressed in $M$. xanthus but not in E. coli: Madozier et al., 1986) and $50 \mu \mathrm{g}$ kanamycin $\mathrm{ml}^{-1}$ and incubated for $6 \mathrm{~d}$ at $28^{\circ} \mathrm{C}$.

Biological assay (biotest) for saframycin Mx1 production. $M$. xanthus DM504/15 and its derivatives were grown for $5 \mathrm{~d}$ at $28{ }^{\circ} \mathrm{C}$ on $\mathrm{S} 46$ agar $(20 \mathrm{ml}$ per plate) without antibiotics. Agar plugs ( $3 \mathrm{~mm}$ diameter) with single colonies were placed onto DST agar freshly overlaid with $10 \mathrm{ml}$ DST agar at $45^{\circ} \mathrm{C}$ and $100 \mu \mathrm{l}$ of an overnight culture of Sarcina lutea. After overnight incubation at $30^{\circ} \mathrm{C}$, the inhibition zones of $S$. lutea were measured. This biotest detects $\geqslant 0.5 \mathrm{ng}$ saframycin $\mathrm{Mx} 1$. Colonies of strain DM504/15 produce 10-25 ng saframycin Mx1 and inhibition zones of 10-14 mm diameter; non-producing mutants did not inhibit growth of $S$. lutea.

Gene disruption of $\boldsymbol{M}$. xanthus DM504/15. pCIB132 derivatives were introduced by conjugation into $M$. xanthus DM504/15 using the same procedure as for the Tn 5 mutagenesis. Kanamycin-resistant transconjugants containing plasmids integrated into the genome via homologous recombination were selected.

DNA manipulations. Standard genetic techniques for in vitro DNA manipulations and cloning were used (Sambrook et al.,
1989). Genomic DNA preparations were performed as described by Neumann et al. (1992). For Southern blots and colony hybridizations the digoxigenin labelling and detection kit from Boehringer-Mannheim and Hybond N-Nylon-membranes from Amersham were used.

Construction of $M$. xanthus DM504/15 genomic libraries. $M$. xantbus DM504/15 total DNA was partially digested with Sau3AI and size-fractionated in 15-40\% (w/v) sucrose gradients. Fractions containing DNA fragments of 23-42 kb were pooled and ligated to pWE15 digested with Bam HI and treated with calf intestine alkaline phosphatase (CIAP). The ligation mixture was packaged in vitro using Gigapack Plus (Stratagene).

DNA sequencing. Double-stranded DNA fragments were cloned into pBluescript $\mathrm{SK}(+)$ and sequenced by the dideoxy nucleotide chain-termination method (Sanger et al., 1977) with dye-labelled primers and an Applied Biosystems Automated Sequencer (model 373A). Universal primer and oligonucleotide primers designed according to the newly obtained DNA sequences were used.

Computer analysis of DNA and protein sequences. The DNA sequences were assembled and analysed using software Version 1.20 from Applied Biosystems and the UWGCG program package version 8.0 (Devereux et al., 1984).

HPLC analysis of saframycin Mx1 production. S45 medium $(20 \mathrm{ml})$ was inoculated with $1 \mathrm{ml}$ cells from a $-70^{\circ} \mathrm{C}$ stock in $20 \%(\mathrm{v} / \mathrm{v})$ glycerol and incubated with shaking for $3 \mathrm{~d}$ at $28{ }^{\circ} \mathrm{C}$. Subsequently a second preculture in $20 \mathrm{ml} \mathrm{S} 45$ medium was inoculated with $5 \%(\mathrm{v} / \mathrm{v})$ of the first culture and incubated with shaking for $3 \mathrm{~d}$ at $28^{\circ} \mathrm{C}$. Then $1.5 \mathrm{ml}$ of the second culture was transferred to a $200 \mathrm{ml}$ Erlenmeyer flask containing $50 \mathrm{ml}$ Saf3 medium [casein peptone, $3 \mathrm{~g} \mathrm{l}^{-1}$; dextrin A-332, $32 \mathrm{~g} \mathrm{l}^{-1}$; $\mathrm{MgSO}_{4} .7 \mathrm{H}_{2} \mathrm{O}, 2 \mathrm{~g} \mathrm{l}^{-1} ; \mathrm{CaCl}_{2} .2 \mathrm{H}_{2} \mathrm{O}, 0.5 \mathrm{~g} \mathrm{l}^{-1}$; sodium citrate, $4 \mathrm{~g} \mathrm{l}^{-1}$; absorber resin XAD 1180 (Rohm and Hass, Frankfurt, Germany), $50 \mathrm{~g} \mathrm{l}^{-1} ; \mathrm{pH} 7 \cdot 2$ ]. After $3 \mathrm{~d}$ shaking at $28^{\circ} \mathrm{C}, 5 \mathrm{ml}$ $5 \%(\mathrm{w} / \mathrm{v})$ casitone was added. After additional incubation for $3 \mathrm{~d}$ at $28^{\circ} \mathrm{C}$ the absorber resin XAD 1180 was harvested on a polyester sieve (Sartorius, B 420-47-N) and eluted with $20 \mathrm{ml}$ $90 \%(\mathrm{v} / \mathrm{v})$ 2-propanol by shaking for $30 \mathrm{~min}$ in $50 \mathrm{ml} \mathrm{Falcon}$ tubes at room temperature. The 2-propanol eluate was centrifuged for $5 \mathrm{~min}$ and the clear supernatant was analysed by HPLC for its saframycin Mx1 content. Reverse-phase HPLC analysis was performed by using a silica-based stationary phase [Lichrospher 60 A RP-18 $(5 \mu \mathrm{m})$, Merck] in a $12.5 \mathrm{~cm}$ column and a phosphate buffer ( $\mathrm{pH} 3$ ) acetonitrile gradient as mobile phase. Saframycin $\mathrm{Mx} 1$ was detected by absorption at $260 \mathrm{~nm}$. Typical yields for strain DM504/15 were 18-24 mg (l culture) $^{-1}$. The detection limit was $3 \mathrm{mg}^{-1}$.

\section{RESULTS}

\section{Tn5 mutagenesis of $M$. xanthus DM504/15 and isolation of saframycin Mx1. non-producers}

$\operatorname{Tn} 5$ and its derivatives have been used to mutagenize $M$. xanthus and to identify and clone a number of genes (Kroos \& Kaiser, 1984; Kroos et al., 1986; Kuner \& Kaiser, 1981). Transposition of $\operatorname{Tn} 5$ into the genome occurs after conjugative transfer of the suicide plasmid pSUP2021 from E. coli to $M$. xanthus (Saulnier et al., 1988). For the saframycin production strain DM504/15, this technique yielded kanamycin- and streptomycinresistant mutants at a frequency of about $1 \times 10^{-5}$ per recipient cell. Southern blots using genomic DNA from 
Table 1. Bacterial strains and plasmids

\begin{tabular}{|c|c|c|}
\hline Strain or plasmid & Characteristics* & Source or reference \\
\hline \multicolumn{3}{|l|}{ E. coli } \\
\hline XL1-Blue & $\begin{array}{l}\operatorname{rec} A 1 \text { end } A 1 \text { gyr } A 96 \text { tbi-1 } \\
\text { bsd } 17 \text { supE44 relA1 lac }\left[\mathrm{F}^{\prime}\right.\end{array}$ & \multirow[b]{2}{*}{ Stratagene Cloning Systems } \\
\hline XL1-Blue MR & $\begin{array}{l}\left.\operatorname{pro} A B \text { laci } I^{a} \text { lac } Z \Delta M 15 \operatorname{Tn} 10\left(\mathrm{Tc}^{r}\right)\right] \\
\operatorname{rec} A 1 \text { end } A 1 \text { gyr } A 96 \text { thi-1 } \\
\sup E 44 \text { rel } A 1 \text { lac } \Delta(m c r A) 183 \\
\Delta(m c r C B-b s d S M R-m r r) 173\end{array}$ & \\
\hline \multirow{2}{*}{\multicolumn{3}{|c|}{ 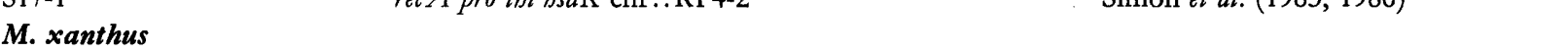 }} \\
\hline & & \\
\hline $\mathrm{Mx} \mathrm{x} 48$ & $\mathrm{Saf}^{+}$, wild-type & Irschick et al. (1988) \\
\hline DM504/15 & $\begin{array}{l}\text { Saframycin } \mathrm{Mx} 1 \text { production } \\
\text { strain, aobtained by } \mathrm{UV} \\
\text { mutagenesis of } M \text {. xanthus } \mathrm{Mx} \times 48\end{array}$ & This study \\
\hline AP66/254 & DM504/15:: $\operatorname{Tn} 5, \mathrm{Saf}^{-} \mathrm{Km}^{\mathrm{r}} \mathrm{Sm}^{\mathrm{r}^{-}}$ & \multirow{2}{*}{ This study, Fig. 4} \\
\hline AP70/9-1 & DM504/15:: $\operatorname{Tn} 5, \mathrm{Saf}^{-} \mathrm{Km}^{\mathrm{r}} \mathrm{Sm}^{\mathrm{r}}$ & \\
\hline \multicolumn{3}{|l|}{ Sarcina lutea } \\
\hline ATCC 9341 & Saframycin $M x 1$ sensitive & American Type Culture Collection \\
\hline \multicolumn{3}{|l|}{ Plasmids } \\
\hline pSUP2021 & $\mathrm{Ap}^{\mathrm{r}} \mathrm{Cm}^{\mathrm{r}} \operatorname{Tn} 5\left(\mathrm{Km}^{\mathrm{r}} \mathrm{Sm}^{\mathrm{r}}\right)$ oriT $(\mathrm{RK} 2)$ & Simon et al $(1983.1986)$ \\
\hline pSUP202 & $\mathrm{Ap} \mathrm{p}^{\mathrm{r}}, \mathrm{Cm}^{\mathrm{r}}$, oriT $(\mathrm{RK} 2)$ & 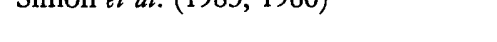 \\
\hline pCIB132† & $\mathrm{Ap}^{\mathrm{r}} \mathrm{Cm}^{\mathrm{r}} \mathrm{Km}^{\mathrm{r}}$ ori $T(\mathrm{RK} 2)$ & J. M. Ligon, personal communication \\
\hline pBluescript II SK(+) & $A \mathrm{p}^{\mathrm{r}}$ & Stratagene Cloning Systems \\
\hline $\begin{array}{l}\text { pWE15 } \\
\text { pAP78/1 }\end{array}$ & Ap ${ }^{r} \mathrm{Km}^{r}$, E. coli cosmid vector & \multirow{3}{*}{ This study } \\
\hline pAP78/1 & $\begin{array}{l}16 \mathrm{~kb} \text { EcoRI fragment of } \\
\text { AP66/254 in pSUP202 }\end{array}$ & \\
\hline $\mathrm{pAP} 78 / 5$ & $\begin{array}{l}8.8 \mathrm{~kb} \text { EcoRI fragment of } \\
\text { AP70/9-1 in pSUP202 }\end{array}$ & \\
\hline pAP93/8 & $\begin{array}{l}\text { Cosmid clone of } M \text {. xantbus } \\
\text { DM504/15 in pWE15 with an } \\
\text { insert of } 42 \mathrm{~kb}\end{array}$ & \multirow{12}{*}{ This study, Fig. 4} \\
\hline pAP101/19 & $\begin{array}{l}\text { Cosmid clone of } M . \text { xantbus } \\
\text { DM504/15 in pWE15 with an } \\
\text { insert of } 38 \mathrm{~kb}\end{array}$ & \\
\hline $\mathrm{pAP} 108 / 3$ & $\begin{array}{l}\text { Cosmid clone of } M \text {. xantbus } \\
\text { DM504/15 in pWE15 with an } \\
\text { insert of } 38 \mathrm{~kb}\end{array}$ & \\
\hline $\mathrm{pAP} 98 / 16$ & $\begin{array}{l}2.4 \mathrm{~kb} \mathrm{BamHI} \text { fragment of } \\
\mathrm{pAP} 93 / 8 \text { in pCIB132 }\end{array}$ & \\
\hline pAP98/17 & $\begin{array}{l}1.6 \mathrm{~kb} \text { Bam HI fragment of } \\
\mathrm{pAP} 93 / 8 \text { in pCIB132 }\end{array}$ & \\
\hline pAP98/22 & $\begin{array}{l}0.8 \mathrm{~kb} \mathrm{BamHI} \text { fragment of } \\
\text { pAP93/8 in pCIB132 }\end{array}$ & \\
\hline $\mathrm{pAP} 98 / 23$ & $\begin{array}{l}0.9 \mathrm{~kb} \mathrm{BamHI} \text { fragment of } \\
\mathrm{pAP} 93 / 8 \text { in pCIB132 }\end{array}$ & \\
\hline $\mathrm{pAP} 98 / 1$ & $\begin{array}{l}3 \mathrm{~kb} E c o \mathrm{RI} \text { fragment of } \mathrm{pAP} 93 / 8 \\
\text { in pCIB132 }\end{array}$ & \\
\hline pAP103/3 & $\begin{array}{l}6 \mathrm{~kb} \text { EcoRI fragment of } \\
\mathrm{pAP} 101 / 19 \text { in pCIB132 }\end{array}$ & \\
\hline pAP110/2 & $\begin{array}{l}7 \mathrm{~kb} E c o \mathrm{RI} \text { fragment of } \\
\mathrm{pAP} 108 / 3 \text { in pCIB132 }\end{array}$ & \\
\hline $\mathrm{pAP} 110 / 11$ & $\begin{array}{l}16 \mathrm{~kb} E c o \mathrm{RI} \text { fragment of } \\
\mathrm{pAP} 108 / 3 \text { in pCIB132 }\end{array}$ & \\
\hline pAP113/3 & $\begin{array}{l}8 \mathrm{~kb} E c o \mathrm{RI} / E c o \mathrm{RV} \text { fragment of } \\
\mathrm{pAP} 108 / 3 \text { in pCIB132 }\end{array}$ & \\
\hline
\end{tabular}

*Saf ${ }^{+1-}$, saframycin $\mathrm{Mx} 1$ production/non-production.

†Derivative of pSUP2021 constructed by reversal of the $5 \mathrm{~kb}$ NotI fragment, followed by removal of the resulting $3 \mathrm{~kb}$ BamHI fragment, leaving a unique Bam HI cloning site. 


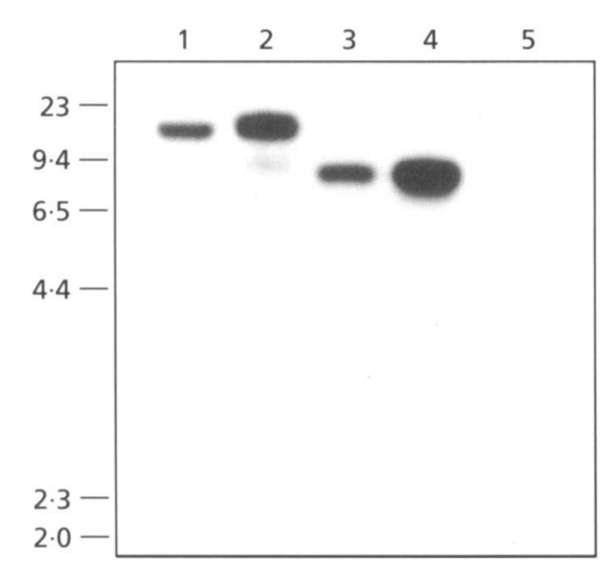

Fig. 2. Southern blot probed with the labelled $3.4 \mathrm{~kb}$ HindIII fragment of Tn5. Lanes: 1, AP66/254; 2, pAP78/1; 3, AP70/9-1; 4, pAP78/5; 5, genomic DNA of the wild-type strain DM504/15. Genomic and plasmid DNAs were digested with EcoRI. Size markers are indicated in $\mathbf{k b}$.

25 independent $\operatorname{Tn} 5$ insertion mutants indicated that the transposon integrated at different sites (data not shown).

In four separate experiments, $2160 \operatorname{Tn} 5$ integrative mutants of $M$. xanthus DM504/15 were generated and screened for saframycin $\mathrm{Mx} 1$ production using the biological assay. A total of $27(1.25 \%)$ saframycin $\mathrm{Mx} 1$ non-producers were found and confirmed by HPLC analysis.

\section{Gene disruption with Tn5-containing DNA fragments derived from saframycin Mx1 non-producers}

Genomic DNA of Tn5-containing saframycin Mx1 nonproducing mutants AP66/254 and AP70/9-1 was digested with EcoRI (does not cut $\mathrm{Tn} 5,5.7 \mathrm{~kb}$ ), ligated to the EcoRI-digested and CIAP-treated conjugative vector pSUP202 and transformed into E. coli S17-1. Two kanamycin-resistant clones were analysed: pAP78/1, derived from AP66/254, contains a $16 \mathrm{~kb}$ EcoRI fragment; pAP78/5, derived from AP70/9-1, contains an $8.8 \mathrm{~kb}$ EcoRI fragment. Southern blot analysis with a Tn 5 -specific probe showed that the cloned fragments had the same size as the genomic fragments (Fig. 2). Chromosomal DNA of M. xanthus DM504/15 showed no cross-hybridization with $\operatorname{Tn} 5$.

The role of these EcoRI fragments in saframycin $\mathrm{Mx} 1$ biosynthesis was confirmed by gene disruption in strain M. xanthus DM504/15. Both plasmids gave kanamycinresistant transconjugants, with frequencies of $1.4 \times 10^{-3}$ for $\mathrm{pAP} 78 / 1$ and $1.4 \times 10^{-4}$ for pAP78/5. Saframycin $\mathrm{Mx} 1$ production determined by the biotest was abolished in 148/153 (pAP78/1) and in 98/176 (pAP78/5; smaller clone) transconjugants. Southern blot analysis showed that the saframycin non-producing transconjugants contained the plasmids integrated by a single crossover in the genome while in the kanamycin-resistant producer strains
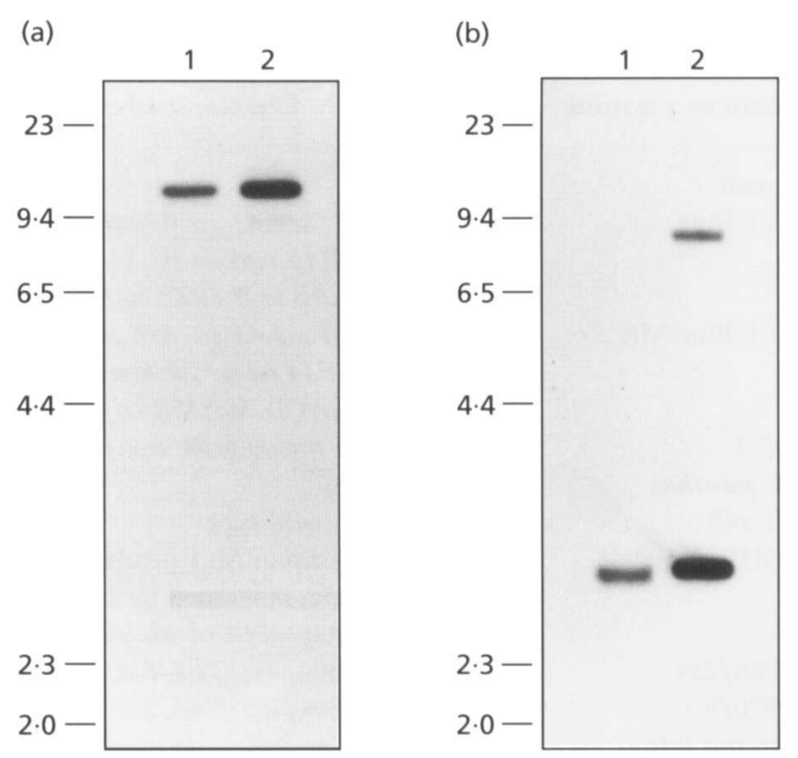

Fig. 3. Southern blots with genomic DNA of the wild-type DM504/15 (lane 1) and cosmid pAP93/8 (lane 2). Total genomic DNA and cosmid DNA were digested with EcoRI and probed with (a) two labelled EcoRI/HindIII fragments of 10 and $2.6 \mathrm{~kb}$ from PAP78/1, and (b) two labelled EcoRI/HindIII fragments of 1.9 and $3.5 \mathrm{~kb}$ from pAP78/5. The $9 \mathrm{~kb}$ fragment in lane 2 is due to cross-hybridization with vector DNA. Size markers are indicated in $\mathbf{k b}$.

$\operatorname{Tn} 5$ had transposed to random sites in the genome (data not shown).

Results obtained in the biotest were confirmed by HPLC analysis for three producing and three non-producing transconjugants from each plasmid: the six strains containing random $\operatorname{Tn} 5$ insertions produced between 20 and $24 \mathrm{mg}$ saframycin $\mathrm{Mx} 1 \mathrm{l}^{-1}$; this is similar to the productivity of the parental strain DM504/15, which produces between 18 and $24 \mathrm{mg}$ saframycin $\mathrm{Mx}^{-1} \mathrm{l}^{-1}$. The transconjugants in which the plasmids had integrated by homologous recombination produced no saframycin. These results demonstrated a direct correlation between the cloned fragments in pAP78/1 and pAP78/5 and saframycin $\mathrm{Mx} 1$ production.

\section{Cloning of the saframycin Mx1 biosynthesis genes from $M$. xanthus DM504/15}

A cosmid library of $M$. xanthus DM504/15 DNA in pWE15 was screened with DNA probes derived from the EcoRI inserts of pAP78/1 and pAP78/5. To avoid crosshybridization between the kanamycin-resistance gene of $\operatorname{Tn} 5$ and the kanamycin-resistance gene of the vector, the central part of $\mathrm{Tn} 5$ was deleted from the EcoRI fragments by digestion with HindIII. As a result two EcoRI/HindIII fragments of 10 and $2.6 \mathrm{~kb}$ for pAP78/1 (probe A) and two EcoRI/HindIII fragments of 1.9 and $3.5 \mathrm{~kb}$ for pAP78/5 (probe B) were obtained. In a first screening, 2500 colonies were analysed with probe $A$ and probe $B$. 


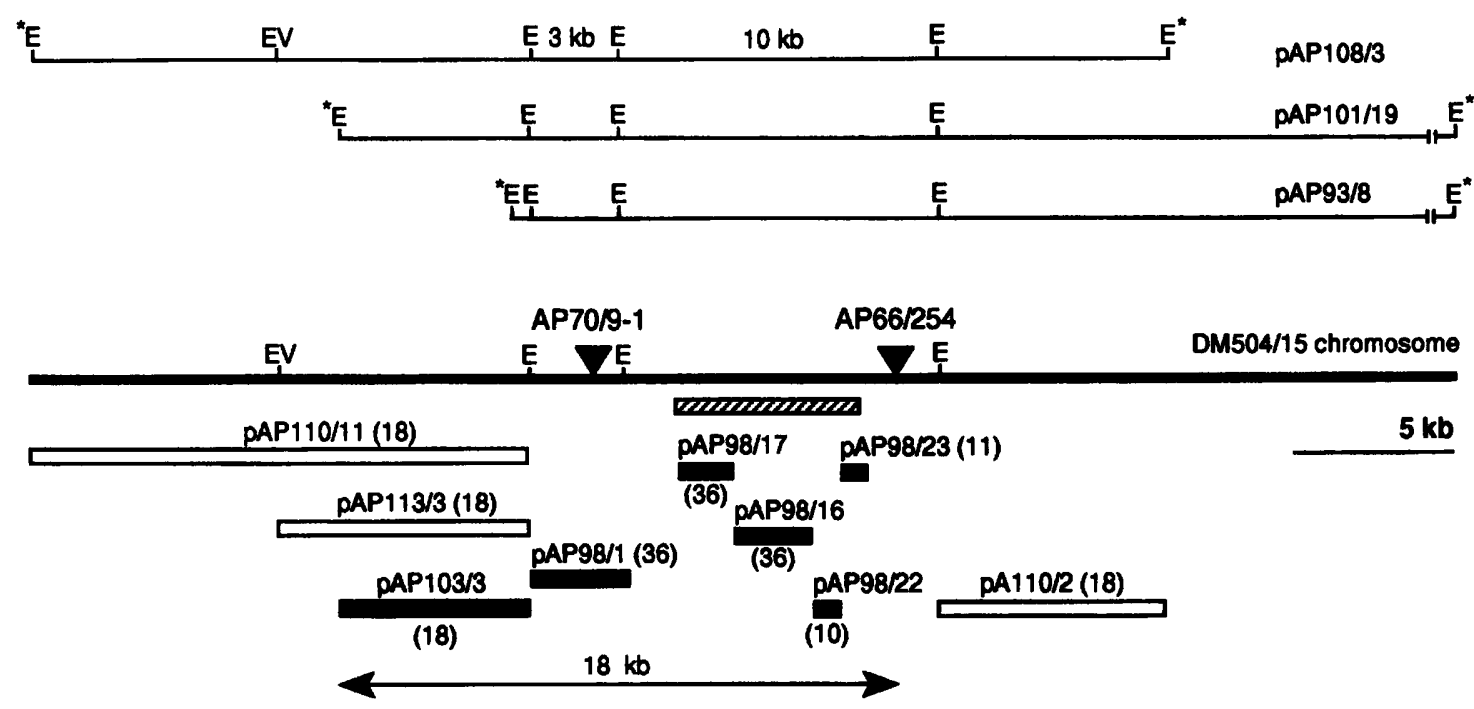

\begin{abstract}
Fig. 4. The saframycin $M \times 1$ biosynthesis locus of $M$. xanthus DM504/15. The cosmids are shown on top. E, EcoRl; E*, EcoRI sites of the vector; EV, EcoRV. Filled triangles indicate the positions of the Tn5 insertions in the non-producing strains AP70/9-1 and AP66/254. The hatched box represents the sequenced region. The bars below show the DNA fragments that were cloned into PCIB132 and used for gene disruption experiments; black bars indicate clones whose insertion into the DM504/15 genome abolished saframycin production; white bars indicate no effect on saframycin production. The numbers in parentheses indicate how many independent clones were analysed for antibiotic production. The arrows at the bottom of the figure indicate the minimal possible size of the saf transcription unit deduced from the gene disruption experiments.
\end{abstract}

One cosmid clone, pAP93/8 (see Fig. 4), hybridized with both DNA probes (Fig. 3a, b), indicating that the sites of Tn 5 insertions in AP66/254 and AP70/9-1 are close to each other (Fig. 4).

As expected, the chromosomal EcoRI fragments of $M$. xantbus DM504/15 detected by probes $\mathrm{A}$ and $\mathrm{B}$ are about $6 \mathrm{~kb}$ (size of Tn5) smaller than the inserts in pAP78/1 and pAP78/5 (Fig. 3). The EcoRI fragments from the cosmid pAP93/8 are of the same size as the chromosomal fragments, indicating that the complete wild-type fragments have been cloned. Additional screening identified the cosmids pAP101/19 and pAP108/3 (Fig. 4). Together the cosmids pAP93/8 and pAP108/3 cover about $58 \mathrm{~kb}$. Fig. 4 shows restriction maps of the cosmids and of the genomic region they represent.

\section{Size of the region involved in saframycin Mx1 biosynthesis}

DNA fragments of the three cosmids pAP93/8, pAP101/19 and pAP108/3 were used for gene disruption experiments. Four Bam HI and four EcoRI fragments were subcloned into the conjugative plasmid pCIB132 and transformed into the E. coli donor strain S17-1 (Fig. 4). All fragments gave kanamycin-resistant (encoded by pCIB132) $M$. xantbus DM504/15 transconjugants, presumably by homologous recombination, with frequencies ranging between $1.4 \times 10^{-3}$ and $1.5 \times 10^{-6}$. The saframycin $\mathrm{Mx} 1$ productivity of these transconjugants was determined with the biotest. The six fragments represented by black bars in Fig. 4 abolished biosynthesis of saframycin Mx1 after integration. Open bars represent fragments whose integration had no effect on antibiotic production and therefore most probably contain the beginning and the end of the saframycin Mx1 biosynthetic gene cluster. To determine the position on the left end of the gene cluster more precisely, plasmid pAP113/3 (Fig. 4) was constructed by a partial EcoRI digestion of pAP110/11 followed by digestion with EcoRV, infilling and subsequent ligation. This plasmid carries an $8 \mathrm{~kb}$ insert and gave saframycin-Mx1-positive transconjugants. Thus the left end of the gene cluster is located within this $2 \mathrm{~kb}$ region. Based on these gene disruption experiments, and on the positions of the $\operatorname{Tn} 5$ integration sites, the size of the region involved in saframycin $\mathrm{Mx} 1$ biosynthesis is at least $18 \mathrm{~kb}$ (Fig. 4).

\section{Sequence analysis}

The nucleotide sequence (Fig. 5) of 5809 bp of the saframycin $\mathrm{Mx} 1$ biosynthetic gene cluster was determined. It has an overall G+C content of $71 \mathrm{~mol} \%$, typical for myxobacteria. Analysis of the sequence with the program CODONPREFERENCE (Devereux et al., 1984) revealed one probably translated ORF (Fig. 5). The ORF (saf $A$ ) has more than 1936 amino acids and its start point and stop codon are outside the sequenced region. Sequence comparison using TFASTA (Devereux et al., 1984) revealed an overall identity of the deduced amino acid sequence of saf $A$ of about $34 \%$ compared to diverse peptide synthetases, for example: gramicidin $\mathrm{S}$ synthetase II from Bacillus brevis (Krätzschmar et al., 1989; Turgay et al., 1992); surfactin synthetase from B. subtilis (Cosmina et al., 1993); pyoverdine synthetase $D$ from Pseudomonas aeruginosa (T. R. Merrimann and others, unpublished, 
1 GCCGTGCTGCंTGCGCCACTA்CACCGGGCAGंGAGGAGCTGCTGCTCGGCACGCCCGTGGCGAACCGGCAGC̈GGCCGGAGCTGGAGCCGGTCATCGGGTTCC

$\begin{array}{llllllllllllllllllllllllllllllllllll}\text { A } & \text { V } & \text { L } & \text { L } & \text { R } & \text { H } & \text { Y } & \text { T } & \text { G } & \mathbf{Q} & \text { E } & \text { E } & \text { L } & \text { L } & \text { L } & \text { G } & \text { T } & \text { P } & \text { V } & \text { A } & \text { N } & \text { R } & \mathbf{Q} & \mathbf{R} & \mathbf{P} & \mathbf{E} & \text { L } & \text { E } & \text { P } & \text { V } & \text { I } & \text { G } & \text { F } & \text { L }\end{array}$ 101 TGGCCAACACGCTCGTGGTCCGCGCGGACCTCACCGGGGATCCTCGCGTGGAGGAGCTGCTGCGCCGCATCCGGGAGACGACCCTGGAGGCCGTGGCGCA

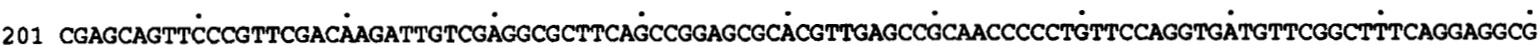

$\begin{array}{lllllllllllllllllllllllllllllllllll}E & Q & F & P & F & D & K & I & V & E & A & L & Q & P & E & R & T & L & S & R & N & P & L & F & Q & V & M & F & G & F & Q & E & A\end{array}$

301 CCTCAGGCGAGGCTCACGTTGGGGGGCCATCCGCTCACGCGGCTGCCGGTGGAACCGGCACCTCCCGGTTCGACCTGTGGCTCTTCCTCACCGAGGACA 401 GCGACGGCATCCAGGGCCTCGTCGAGTACAGCACGGACCTGTTCGAGGCGGACACCATCGACAGGCTGACGCGGCACTACCAGGCGGTGGTGGAGGGCCT $\begin{array}{llllllllllllllllllllllllllllllllll}D & G & I & Q & G & \text { L } & V & E & Y & S & T & D & \text { L } & \text { F } & \text { E } & \text { A } & \text { D } & \text { T } & \text { I } & \text { D } & R & \text { L } & \text { T } & \text { R } & \text { H } & \text { Y } & \text { Q } & \text { A } & \text { V } & \text { V } & \text { E } & G & \text { L }\end{array}$ 501 GCTCCGGGGCGGCCACCAGCGCGTCTCGCAGCTCTCGCTGCTCACGGAGAAGGAGCGCGCGGACTCGCGGCCAGCGCGTTCCGCGCCGAGCCAGAGCCC

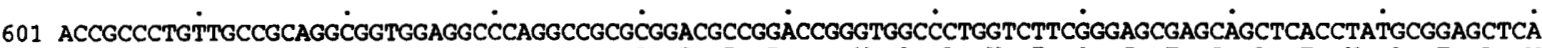
$\begin{array}{llllllllllllllllllllllllllllllllllll}\text { T } & \text { A } & \text { L } & \text { L } & \text { P } & \mathbf{Q} & \mathbf{A} & \mathbf{V} & \mathbf{E} & \mathbf{A} & \mathbf{Q} & \mathbf{A} & \mathbf{A} & \mathbf{R} & \mathbf{T} & \mathbf{P} & \mathbf{D} & \mathbf{R} & \mathbf{V} & \mathbf{A} & \mathbf{L} & \mathbf{V} & \mathbf{F} & \mathbf{G} & \mathbf{S} & \mathbf{E} & \mathbf{Q} & \mathbf{L} & \mathbf{T} & \mathbf{Y} & \mathbf{A} & \mathbf{E} & \mathbf{L} & \mathbf{N}\end{array}$ 701 ACGCCCGGGCCAACCGGCTCGCCCGCCTGCTGAAGACCCG̈GGGCGTGGGCGCCGAGCGCCGGTGCGCCGTCTGCATGGAGTGCTCGCCGGACCTGGTCGT $\begin{array}{lllllllllllllllllllllllllllllllllll}\mathbf{A} & \mathbf{R} & \mathbf{A} & \mathbf{N} & \mathbf{R} & \mathbf{L} & \mathbf{A} & \mathbf{R} & \mathbf{L} & \mathbf{L} & \mathbf{K} & \mathbf{T} & \mathbf{R} & \mathbf{G} & \mathbf{V} & \mathbf{G} & \mathbf{A} & \mathbf{E} & \mathbf{R} & \mathbf{R} & \mathbf{C} & \mathbf{A} & \mathbf{V} & \mathbf{C} & \mathbf{M} & \mathbf{E} & \mathbf{C} & \mathbf{S} & \mathbf{P} & \mathbf{D} & \mathbf{L} & \mathbf{V} & \mathbf{V}\end{array}$ 801 CTCCCTGCTG̈GCGGTGCTCAAAGGCGGGGGGGGGCCTACGTCंCCAGTGGACCCCGCGGTATCCGCTGGAGCGGGTGCGGTACÄTGCTCGAGGÁCGCGCGGGCC $\begin{array}{lllllllllllllllllllllllllllllllllll}S & \text { L } & \text { L } & \text { A } & \text { V } & \text { L } & \text { K } & \text { A } & \text { G } & \text { G } & \text { A } & \text { Y } & \text { V } & \text { P } & \text { V } & \text { D } & \text { P } & \text { R } & \text { Y } & \text { P } & \text { L } & \text { E } & \text { R } & \text { V } & \text { R } & \text { Y } & \text { M } & \text { L } & \text { E } & \text { D } & \text { A } & R & \text { A }\end{array}$ 901 CAGGTGCTGCTCACCCGGCGGGAGCTGGCCCACCATGGCGAGGGCATCCCGCACGTTGTGTCTCTCCCG

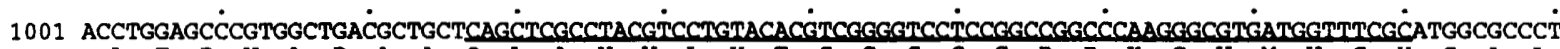

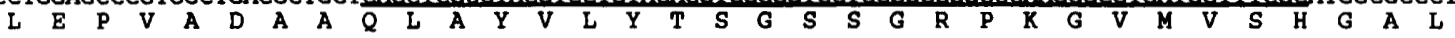

1101 CGCCAACTTCTTGACGACCAंTGGCCCGGGAGCCGGGCTTECGCGCCGAGGACGTGCTCGCCGCGGTGACCACGTTCTCCTTCGACATCGCCGCGCTCGAG

1201 CTGTACCTGĊCGCTGGTTCÄGGCGCGCGGGTGGTGATGGCCACCCGTGÄGCAGGCCGCǴGATGGGCGCG்CCTGTCCGGGGTGTTGGCGCGGCACGGGG

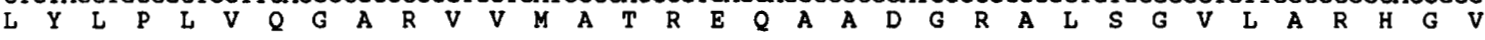
1301 TGACGGTGATGCAGGCCACTCCGGCCACCTGGCGCATGCTGGCCGACGCGGGCGGGGCTCCCGGCACGGGCTTCACCGTGCTGTGCGGAGGGGAGGCGCT 1401 GCCCCAGGAC̈CTCGCCGACGंCGCTCACCGĆGAACGGGGCCंCGGGTGTGGÄACCTTTATGǴCCCCACGGÁ̈ACCACGGTGTGGTCCTGCCGCAAGCGGCTG

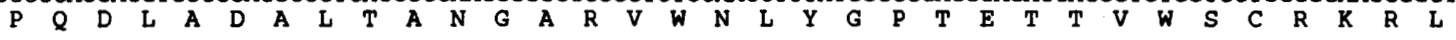

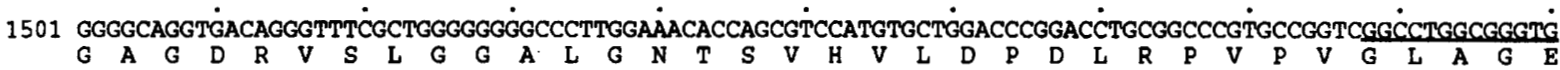

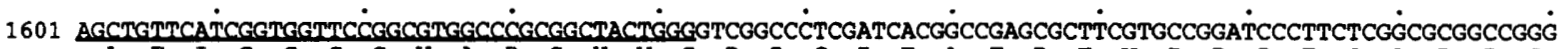

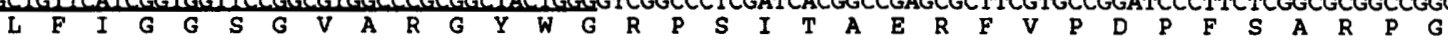

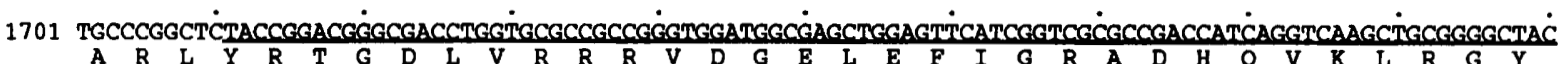

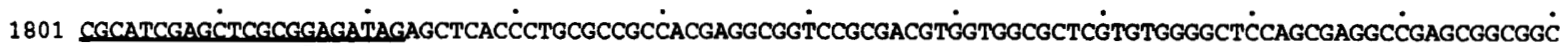

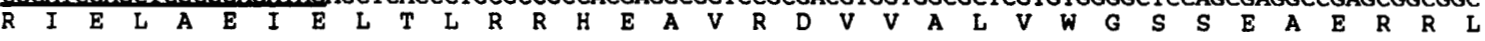
1901 TCATCGCCTACGTGGTGCCGGTCGCGGCGCAGGGCCGGGGACGACAACCCTGGCCCACCGGCTGCGCGAGCACGCCCGGGCCGTGCCTGCCTGAATACAT $\begin{array}{lllllllllllllllllllllllllllllllllllllll}I & A & Y & V & V & P & V & A & A & Q & G & R & G & R & Q & P & W & P & T & G & C & A & S & T & P & G & P & C & L & P & E & Y & M\end{array}$ 2001 GGTGCCTTCGGCCAACGTGCंTCCTGGATGCGCTTCCCCTGACGCCAACGGCAAGGTGGACCGACGCTCCCTGCCGGACCCGAGGTCGGTGATGGCTCGC 2101 GGCGGGGCGÄTGCACGTGGCTTCCTCGCACCंGAGACGGAGG̈GCCGCATTGCCACCATTTGG̈ATGCAACTGCTCGGCTGTGACCAGGMGGGÄGTGAAGGACǴ

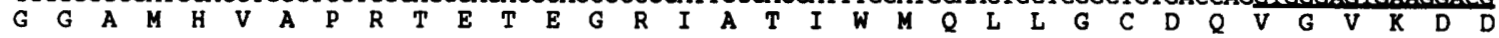

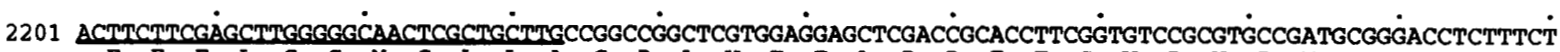

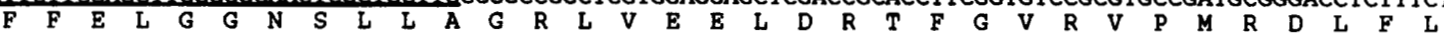

2301 CGACGCGACGATTGCCAACCंTCGCCGCGGTGATTGATGGGCGTCGCCGGAAGGCGTCCGTTGTGGAGGCGCCGCACGTGGACGAGTTGGTGAGCGGATTG

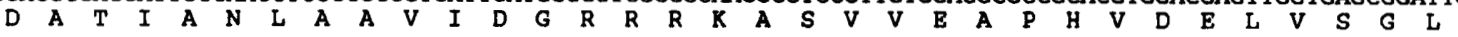

2401 ACCGACGACGAAGTGGAGGCGCTCTTGAACGAGCCACAGTTGGGCCATGTGAACACTCAGCAACGTGAAGGAGGGGAGCAGGTGAGTTCGTCCGAGAGCG

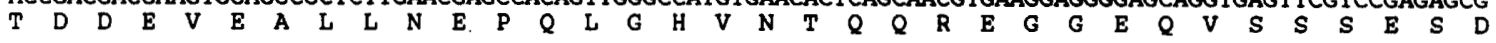
2501 ACAACGGCCG்CGCGCCGCĆGAGGAGAAGÁGAGCTACGCTGGCCAGGCTGCTGCGGGACǴGACGTCTCCAGGGCCACGCGAACCTGTCGCCCGGATCAGCG $\begin{array}{lllllllllllllllllllllllllllllllllllll}N & G & R & R & A & A & E & E & K & R & A & T & L & A & R & L & L & R & D & G & R & L & Q & G & H & A & N & L & S & P & D & Q & R\end{array}$

2601 GCGGCTCTGGATGCTGCTGCAACTCGACGGGACTCTGCCGGCACAGGTGCTGGCGGCCTACGCGCTGAGG̈GGGCGTTGGACCTGGCCGTGTTGCAGCAG $\begin{array}{llllllllllllllllllllllllllllllllllll}R & L & W & M & L & L & Q & L & D & G & T & L & P & A & Q & V & L & A & A & Y & A & L & R & G & A & L & D & L & A & V & L & Q & Q\end{array}$

2701 GCCATCGCCG்AGTGGCGAǴCCGCAACGAGGTCCTGCGCAGCACGTTCAÄGACATGGGGGGGACGCCGCTTGCGCGTCGCCAGGCCGGTGATGGAGCTGG

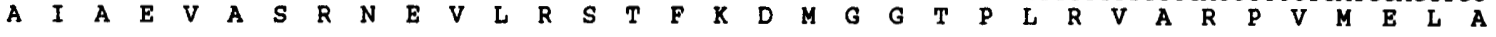
2801 CGCTCGCGGT'GACGGAGGCGGCCGGCACAGGCCTGGATGACGCCCTGCAACGGCTCGCTCGGCAGGAGCTGGGCGAGCGGCTCGAGCCGGCCACCGGGCC $\begin{array}{llllllllllllllllllllllllllllllllll}\text { L } & A & V & T & E & A & A & G & T & G & L & D & D & A & L & Q & R & \text { L } & A & R & Q & E & L & G & E & R & L & E & P & A & T & G & P\end{array}$ 2901 GCTGTTGCGCCTGCACCTCGTCAGGCTCGGGGCCGAGGAGCACCTGCTGCTCGTCAAGGCGCACGAGCTGATCTCCGACGAGCCTTCCCTGGAGGCGCTC

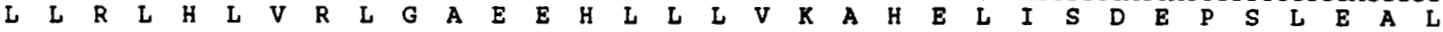

Fig. 5. For legend see facing page. 
3001 ATTCGGGAGGTGCTCGCCACGTATGGCGCCCTCCTGCGCG̈GCGAGCAGTCCGCGGCGTCC̈TCCGTGTCCGCCTACGCCGÄGTACGCCGCGCGGGAGCAGG

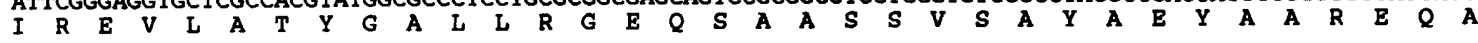
3101 CCTGGCTGAGCGGGCCGGTGTGTGGCCAGCAGCTCGAACACTGGCGCCGGAAGCTCACGGACCTGCCCCTGCTGCGGCTCंTTCACCGATCGGCCCGCGTCC

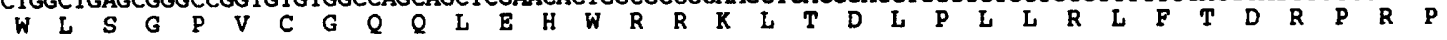
3201 CGTCATCAAGACGCACCGCTGCGACTCAGTCTCCACCCTG̈CTGCCGCTCGAGCTGTCGCGGCGGATGGAAGCGCTGGCCTCGCGCAACGGGGGCCTGCGC

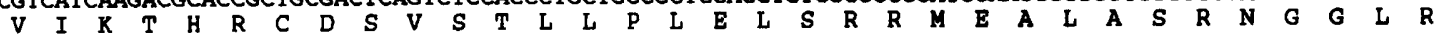

3301 GCGGCGGTGCंTGGCCGGCT'TTCAGGTGCTGCTGTCCCGGTACACCGGGCAATCCGATGTGACAGTGGGCG'TTCGCGCCGACCTCCGGAGCGAAGCCGAAC

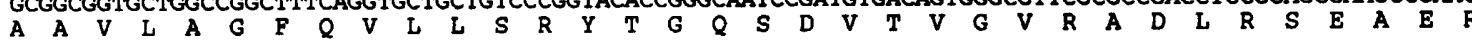
3401 GAGGCCGGCTCCTCGGGCCCंGCCAGCACCG̈CCCTGGTCCTGCGGACCGACCTGCGCGGCGAGCCGTCCTTCATGGAGACG̈CTCCTGCGCG̈TCGACGTGGC

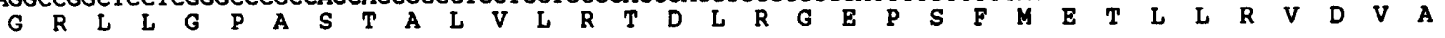

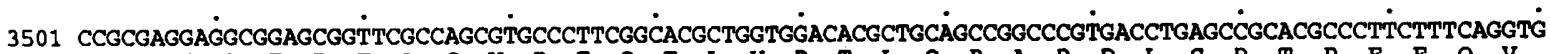

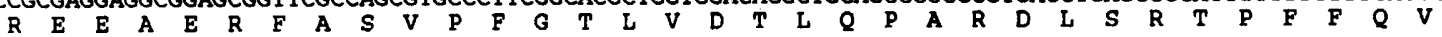
3601 ATGTACCTGTTTTCGGGATGCंGCGCGAGGAGCTGGCGGTTGGGCGCCGGCCTGCGCGCCCTGGCGCAGGCGTंTGCCGTTCGG̈CACCACCCCGGTGGACATCA

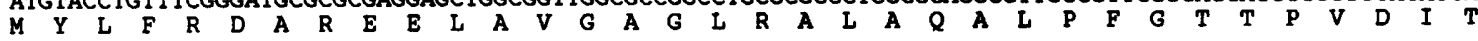
3701 CCCIGGCGGCGACCGCCACCंGAGCAGGGCC̈TCCACCTGCGCGTCGACTTCAACTCCGACCंTGTACGACGCGAGCACCGCǴCGGCGCCTGTTTGGGCCACCT L A A T A T E Q G L H L R V D F N S D L Y D A S T A R R L L L 3801 GCGCACGCTGCTGTCCGCGGCGGTGGACGCTCCGGGGAAGTCCATCGCCC̈GGCTGCCGCTGCTCGCCGAGGAGGAGTGGÄGGCAGGTCTTICGGCGACTGG R T L L S A A V D A P G K S I A R L P L L A E E E W R Q V F G D W

3901 AACCAGGCCGAGCACGCCCTCCCGTCGCGCTTTCTGCACGAGCTCGTCGAGGAGCAGGCGGGCGCGCACCCCCGCATGCCGT́TGGCCGTCACG̈TGCGAGGGCCं N Q 4001 ACCAGCTCACCTACGCCGAGCTGGATGCGCACGCCAACCÄGCTCGCCCATCACCTGCGCCAACTCGGGCTGGCTCCGGAÄGTCGGGTGGCGATCTGCCT Q L L T Y A E L D A H A N Q L A H H L R Q

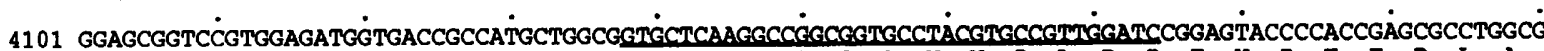

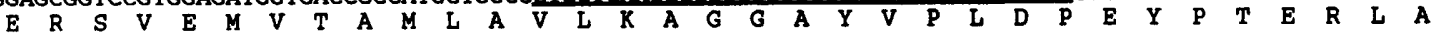

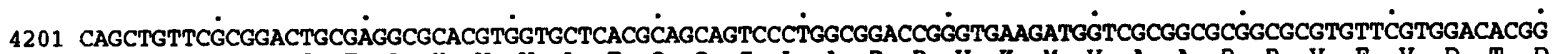

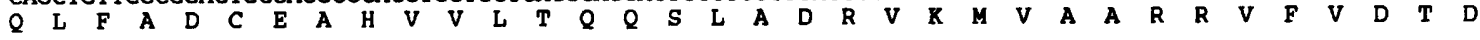

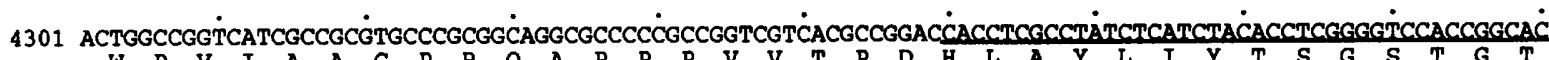
4401 GCCCAAGGCGGTGATGCTCTCTCACCGCGGCATCGTGAACAATCTCGCGTGGCGTCAGCGCACCTGGCCGTTTTCGGCGGAGGACCGGGTGCTGCAGAAC

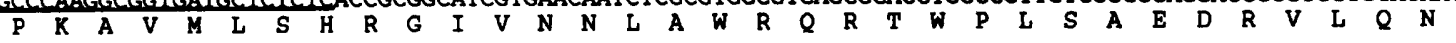

4501 CACTCCTTCAGCTTCGACCCGTTCGGTGTGGGCCACCTTCTGGCCGCTCCTGGTGGGGGCCंAGAGCCGTGC̈TCACCCCGTCOCGGCCAGCACTACGACAGCA $H$
$H$

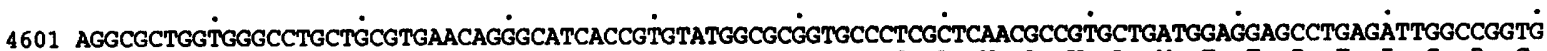
A L V G L L R E Q G I T V Y G A V P S L N 4701 CACCCACCTGCGGTACGTGCंTGAGCGGCGC̈CGAGCCCTCACTGGCGGCCTGCAGCGCGGCATCTTCTCGCGCGTCTCCG̈CCGCCGTCGCंCAACCTCTAC T H L R Y V L S G A E A L T G G L Q R G I F S R V S A A V A N L Y 4801 GGCCGGACGGAGACCACCATCGACGCCACGGCATGGAACTGCCCGCGCGTGGATGCCCC GGAGGACGCTCCCATCGGTCGGCCAATCGCCAACCTGCGGA

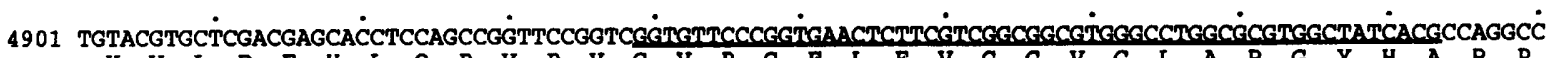

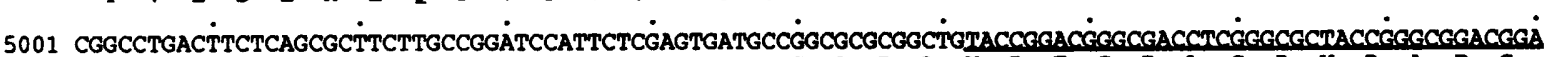
$G$ L T S Q R F L P D P F S S D A G A R L Y R T G D L G R Y R A D G

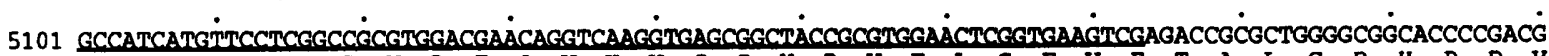
A I M F L G 5201 TGCGCGAGGCCATCGTCGTCGCGCGTGAGGGCCTGCAGGGCATCAAGCGGCTGGTGGCTIACGTCACGCCCGCCAAGGGGGGCACGCCGGAGGCTCGCTC 5301 GCTCACGGCATTCCTCGAGÄAGATTCTGCCGGCGTACATGATTCCGCCGGTGTTCGTCATCGTCAACGAGCTGCCGAAGÄTGCCCAGCGGCAAGGTCAACं

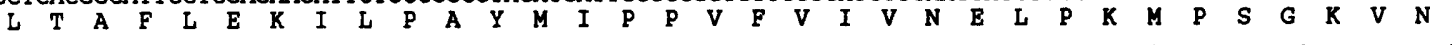
5401 CGCAATGCCCंTGCCTGCCCCGCAGATGGACCGGCCGGACACCGCGGGCGCCTACGTCGCTCCGCGCACGCंCCCTGGAGGÁTGAGATTGCCTCGGCCTTCG $R$
$R$

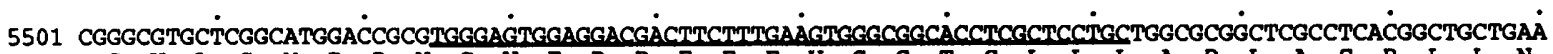
G V L G M D R V G V E D D 5601 CCGCTTCCAGATTGCCATCCंCGGTGCACCAGTTCTTCAÄGATTCCCACGGTGGCTGGGGTGGCGAACGTGGTGGAGACCंTACCAGCGCGAGGGCCTTGAT

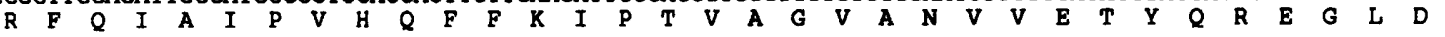
5701 GCCGTGCTGATTGAACCAGCATGCCACGCGGCTGGACGCCGACGCTTCGCTGGCGCCGGACATCTCCCCCGAAGGGTTGCC̈GCTGGCGAACTACCTCGCCC

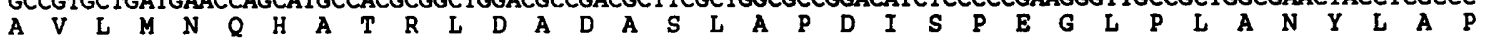
5801 CGTCCTCCG

$S \mathrm{~s}$

Fig. 5. Nucleotide sequence of $5809 \mathrm{~kb}$ from the saframycin $M \times 1$ biosynthetic region of $M$. xanthus DM504/15. The deduced amino acid sequence of the ORF is given below the DNA sequence in single-letter code. Regions containing core sequences of amino-acid-activating domains are overlined. 


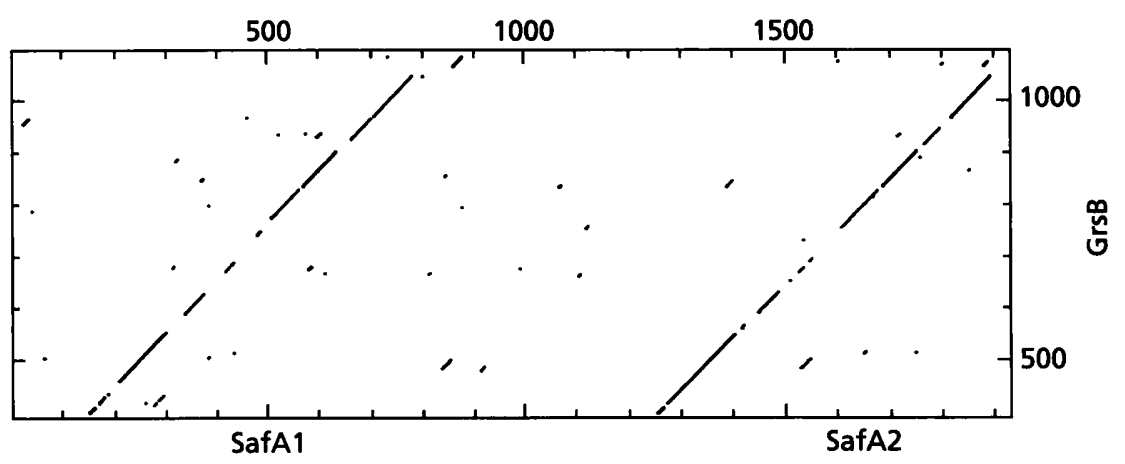

Fig. 6. Amino acid sequence comparisons of the deduced SafA protein and an amino-acid-activating domain (amino acids 400-1100) of the GrsB protein (Turgay et al., 1992) of B. brevis. A window of 30 and a stringency of 16 were used with the programs COMPARE and DOTPLOT version 8.0 of the UWGCG package.

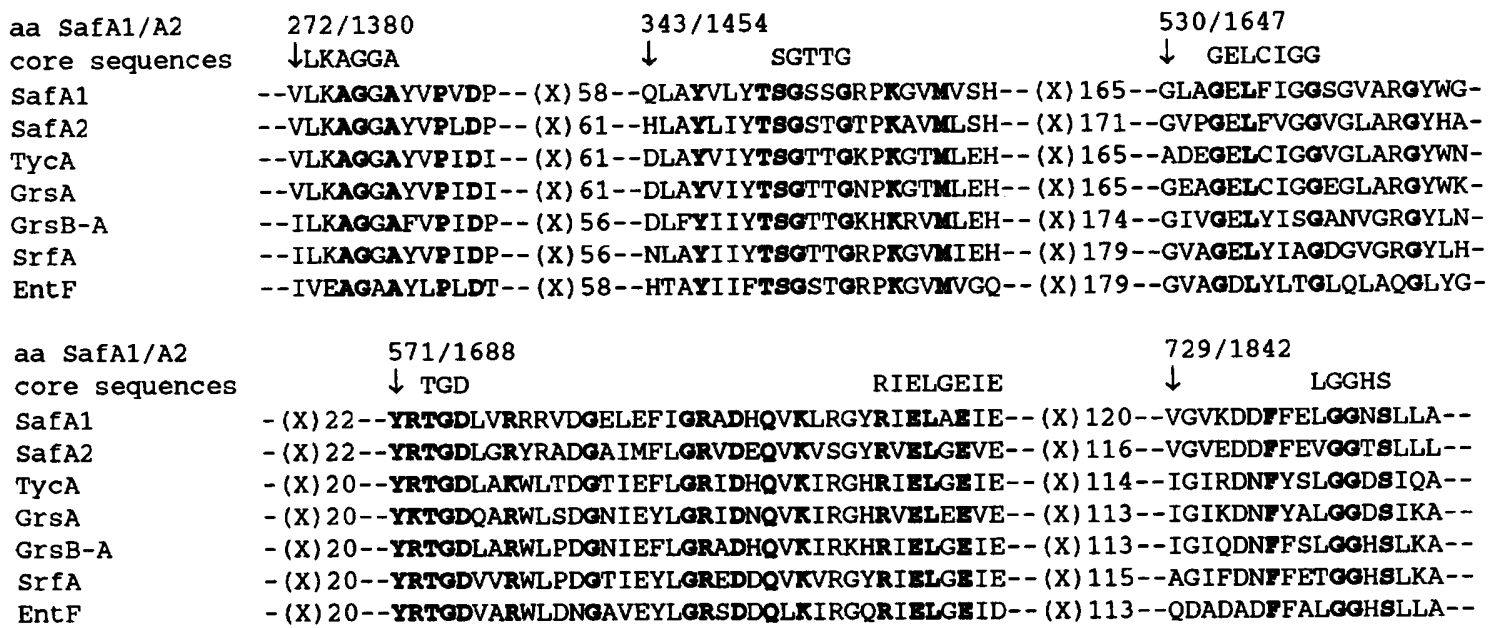

Fig. 7. Conserved amino acid sequences in the SafA domains 1 and 2 and their comparison with presumably homologous sequences from other organisms. GrsA, gramicidin S synthethase I of B. brevis (Hori et al., 1989); GrsB-A, gramicidin S synthethase II of B. brevis (Turgay et al., 1992); EntF, serine-activating enzyme in enterobactin synthesis (Rusnak et al., 1991); TycA, phenylalanine-activating enzyme in tyrocidine biosynthesis (Weckermann et al., 1988); SrfA, surfactin synthetase (Cosmina et al., 1993). Perfectly conserved amino acids are printed bold. Numbers at the top indicate the positions of the amino acids (aa) within SafA. Numbers between the amino acids indicate the distances between these sequences. The core sequences were defined by Marahiel (1992).

EMBL accession number U07359). A COMPARE-DOTPLOTanalysis (Devereux et al., 1984) of the amino acid sequence of SafA with itself revealed two similar domains of $43 \%$ identity, SafA1 (approximately amino acids 200-800) and SafA2 (approximately amino acids 1300-1900), of about 600 amino acids and spaced by about 500 amino acids. SafA1 and SafA2 show $35 \%$ identity and $59 \%$ similarity to amino-acid-activating domains of known peptide synthetases. Fig. 6 shows a DOTPLOT comparison with the gramicidin S synthetase II from Bacillus brevis. Peptide synthetases are multifunctional enzymes, employing the thiotemplate mechanism (Kleinkauf \& von Döhren, 1990), harbouring domains of about 600 amino acids, containing at least six highly conserved core sequences (Marahiel, 1992). Fig. 7 shows a comparison of SafA1 and SafA2 with different amino-acid-activating domains of peptide synthetases. The core sequences LKAGGA, SGTTG, GELCIGG, TGD, RIELGEIE and LGGHS, as well as the spacing between them, are well conserved in SafA1 and SafA2.

\section{DISCUSSION}

Two saframycin non-producing mutants of $M$. xantbus DM504/15 were isolated after Tn 5 mutagenesis. Cloning of the Tn5-containing DNA fragments from these mutants and their integration by homologous recombination (single crossover insertion of suicide plasmids introduced by interspecific RP4-mediated conjugation) into the producer strain DM504/15 (Fig. 4) again gave non-producing mutants. This proved that antibiotic nonproduction was caused by the insertions and not by spontaneously occurring secondary mutations, which are common in some systems ( $\mathrm{T}$. Kieser, personal communication). 
Cosmid cloning and restriction mapping of the $\operatorname{Tn} 5$ containing DNA regions showed that the sites of transposon insertion were about $9 \mathrm{~kb}$ apart in the DM504/15 genome (Fig. 4), suggesting that they are located within a specific saframycin biosynthesis gene cluster. Another possibility would have been that global activators of antibiotic biosynthesis (Adamidis et al., 1990, 1992; Lawlor et al., 1988), which tend to be scattered in bacterial genomes, could have been inactivated.

The region containing the non-mutated saframycin biosynthetic gene cluster was cloned in $E$. coli on three overlapping cosmids (Fig. 4) spanning $58 \mathrm{~kb}$ of DNA. Within this region, saframycin production genes were located by gene disruption in a central region of at least $18 \mathrm{~kb}$. The upper limit of the size of the gene cluster cannot be deduced from these experiments because only integration of fragments internal to transcription units is mutagenic.

Sequencing of $5.8 \mathrm{~kb}$ of this region (Fig. 5) revealed extensive similarity to known peptide synthetases (Figs 6 and 7), providing virtual proof that the gene cluster contains structural genes for saframycin $\mathrm{Mx} 1$ biosynthesis. Within the deduced amino acid sequence of SafA, two peptide synthetase modules, SafA1 and SafA2 (Fig. 6), were identified on a single ORF, a common feature of peptide synthetases (Cosmina et al., 1993; Smith et al., 1990; Turgay et al., 1992). Known active sites and core regions of peptide synthetases (Fig. 7) are conserved in SafA1 and SafA2, suggesting that they may both be active and a part of a giant protein. The biological significance of the first core (LKAGGA) is unknown, but the SGTTGXPKG (Gocht \& Marahiel, 1994), the TGD (Gocht \& Marahiel, 1994) and the KIRGXRIEL (PavelaVrancic et al., 1994; Tohika et al., 1993) core sequences could be assigned to ATP binding and hydrolysis. The serine of the core sequence LGGXS could be shown to be the site of thioester formation (D'Souza et al., 1993; Schlumbohm et al., 1991; Vollenbroich et al., 1993) and 4'phosphopantetheine binding (Stein et al., 1994). These findings, together with the fact that saframycin Mx1 (Fig. 1 ) is synthesized from amino acids (Trowitzsch-Kienast $e t$ al., 1988), support the hypothesis that non-ribosomal peptide bond formation via the thiotemplate mechanism (Kleinkauf \& von Döhren, 1990) is involved in the biosynthetic pathway of saframycin $\mathrm{Mx} 1$ and that $\operatorname{saf} A$ encodes the corresponding peptide synthetase. According to this mechanism, amino acids are activated as aminoacyladenylates by ATP hydrolysis and subsequently covalently bound to the enzyme via carboxyl-thioester linkages. Then, in further steps, transpeptidation and peptide bond formation occur.

It will be necessary to sequence the full length of $\operatorname{saf} A$, and further genes involved in saframycin $\mathrm{Mx} 1$ production, to achieve a precise understanding of the saframycin biosynthetic operon. Nevertheless, the results presented in this study are consistent with findings about antibiotic genes in other myxobacteria, which are arranged as clusters (Schupp et al., 1995; Tolchinsky et al., 1992; Varon et al., 1992), as well as in other systems (reviewed by Hopwood \& Khosla, 1992). In addition, the genes characterized are similar in their sequence and organization to other antibiotic biosynthesis genes (Cosmina et al., 1993; Rusnak et al., 1991; Turgay et al., 1992). The cloning and characterization of biosynthetic genes for peptide antibiotics produced by myxobacteria is a prerequiste for the understanding of the regulatory mechanisms that govern expression of these secondary metabolites and will provide further insight into the regulation of saframycin $\mathrm{Mx} 1$ production in $M$. xanthus.

\section{ACKNOWLEDGEMENTS}

We are grateful to J.M. Ligon and G. Jarai for comments and correction of the manuscript. We thank J. Heim for supporting the project, Hans Reichenbach for providing the original saframycin $\mathrm{Mx} 1$ production strain, and $\mathrm{K}$. Hess and H.B. Jenny for performing the HPLC analysis.

\section{REFERENCES}

Adamidis, T. \& Champness, W. (1992). Genetic analysis of $a b s B$, a Streptomyces coelicolor locus involved in global antibiotic regulation. $J$ Bacteriol 174, 4622-4628.

Adamidis, T., Riggle, P. \& Champness, W. (1990). Mutations in a new Streptomyces coelicolor locus which globally block antibiotic biosynthesis but not sporulation. J Bacteriol 172, 2962-2969.

Arai, T., Takahashi, K. \& Kubo, A. (1977). New antibiotics, saframycins A, B, C, D, and E. J Antibiot 30, 1015-1018.

Arai, T., Takahashi,K., Ishiguro, K. \& Mikami, Y. (1980). Antitumor antibiotics, saframycin A and C. Gann 71, 790-796.

Arai, T., Yazawa, K., Takahashi, K., Maeda, A. \& Mikami Y. (1985). Directed biosynthesis of new saframycin derivates with resting cells of Streptomyces lavendulae. Antimicrob Agents Chemother 28, 5-11.

Cosmina, P., Rodriguez, F., de Ferre, F., Grandi, G., Perego, M., Venema, G. \& van Sinderen, D. (1993). Sequence and analysis of the genetic locus responsible for surfactin synthesis in Bacillus subtilis. Mol Microbiol 8, 821-831.

Devereux, J., Haeberli, P. \& Smithies, O. (1984). A comprehensive set of sequence analysis programs for the VAX. Nucleic Acids Res 12, 387-395.

D'Souza, C., Nakanno, M. M., Corbell, N. \& Zuber, P. (1993). Aminoacylation site mutations in amino acid-activating domains of surfactin synthetase: effects on surfactin production and competence development in Bacillus subtilis. J Bacteriol 175, 3502-3510.

Gerth, K. H., Irschik, H., Reichenbach, H. \& Trowitzsh, W. (1982). The myxovirescins, a family of antibiotics from Myxococcus virescens (myxobacterales). J Antibiot 35, 1454-1459.

Gocht, M. \& Marahiel, M. A. (1994). Analysis of core sequences in the $\mathrm{D}$-Phe activating domain of the multifunctional peptide synthetase TycA by site-directed mutagenesis. $J$ Bacteriol 176, 2654-2662.

Hopwood, D. A. \& Khosla, C. (1992). Genes of polyketide secondary metabolic pathways in microorganisms and plants. In Secondary Metabolites: Their Function and Evolution (Ciba Foundation Symposium 171), pp. 88-112. Edited by D. J. Chadwick \& J. Whelan. Chichester: John Wiley. 
Hori, K., Yamamoto,Y., Minetoki, T., Kurotsu, T., Kanda, M., Miura, S., Okamura, K., Furujama, J. \& Saito, Y. (1989). Molecular cloning and nucleotide sequence of the gramicidin $\mathrm{S}$ synthetase 1 gene. J Biochem 106, 639-645.

Irschick, H., Trowitzsch-Kienast, W., Gerth, K., Hofle, G. \& Reichenbach, H. (1988). Saframycin $\mathrm{Mx} 1$, a new natural saframycin isolated from a myxobacterium. J Antibiot 41, 993-998.

Ishiguro, K., Sakiyama, S., Takahashi, K. \& Arai, K. (1978). Mode of action of saframycin $A$, a novel heterocyclic quinone antibiotic. Inhibition of RNA synthesis in vivo and in vitro. Biocbemistry 17, $2545-2550$.

Ishiguro, K., Takahashi, S., Yazawa, K., Sakiyama, S. \& Arai, K. (1981). Binding of saframycin $A$, a heterocyclic quinone anti-tumor antibiotic, to DNA as revealed by the use of the antibiotic labeled with $\left[{ }^{14} \mathrm{C}\right]$-tyrosine or $\left[{ }^{14} \mathrm{C}\right]$-cyanide. $J$ Biol Chem 256, 2162-2167.

Kishi, K., Yazawa, K., Takahashi, K., Maeda, A. \& Arai, K. (1984). Structure-activity relationships of saframycins. $J$ Antibiot 37, $847-852$.

Kleinkauf, H. \& von Dobhren, H. (1990). Nonribosomal biosynthesis of peptide antibiotics. Eur J Biochem 192, 1-15.

Krätzschmar, J., Krause, M. \& Marahiel, M. A. (1989). Gramicidin $\mathrm{S}$ biosynthesis operon containing the structual genes $\operatorname{grs} A$ and $\operatorname{grs} B$ has an open reading frame encoding a protein homologous to fatty acid thioesterase. J Bacteriol 171, 5422-5429.

Kroos, L. \& Kaiser, D. (1984). Construction of Tn5 lac, a transposon that fuses lac $Z$ expression to exogenous promoters, and its introduction into Myxococcus xanthus. Proc Natl Acad Sci US A 81, $5816-5820$

Kroos, L., Kuspa, A. \& Kaiser, D. (1986). A global analysis of developmentally regulated genes in Myxococcus xanthus. Dev Biol 117, 252-266.

Kuner, J. M. \& Kaiser, D. (1981). Introduction of transposon Tn5 into Myxococcus for analysis of develomental and other nonselectable mutants. Proc Natl Acad Sci US A 78, 425-429.

Lawlor, E. J., Baylis, H. A. \& Chater, K. F. (1988). Pleiotropic morphological and antibiotic deficiencies result from mutations in a gene encoding a tRNA-like product in Streptomyces coelicolor A3(2). Genes \& Dev 1, 1305-1310.

Lown, J.W. , Joshua, A. V. \& Lee, J. S. (1982). Molecular mechanisms of binding and single-strand scission of desoxyribonucleic acid by the antitumor antibiotics saframycin $\mathrm{A}$ and $\mathrm{C}$. Biochemistry 21, 419-428.

Madozier, P., Genilloud, O., Giraud, E. \& Gasser, F. (1986). Expression of Tn5-encoded streptomycin resistance in E. coli. Mol \& Gen Genet 204, 404-409.

Marahiel, M. A. (1992). Multidomain enzymes involved in peptide synthesis. FEBS Lett 307, 40-43.

Mikami, Y., Takahashi, K., Yazawa, K., Arai, T., Namikokoshi, M., Iwasaki, S. \& Okuda, S. (1985). Biosynthetic studies on saframycin A, a quinone antitumor antibiotic produced by Streptomyces lavendulae. J Biol Chem 260, 344-348.

Nakatsubo, F., Fukuyama, T., Cocuzza, J. \& Kishi, Y. (1977). Synthetic studies toward mitomycins. II. Total synthesis of $d l$ porfiromycin. J Am Chem Soc 99, 8115-8116.

Neumann, B., Pospiech, A. \& Schairer, H. U. (1992). Rapid isolation of genomic DNA from gram-negative bacteria. Trends Genet 8, 332-333.

Pavela-Vrancic, M., Pfeifer, E., Schroder, W., von Dobren, H. \& Kleinkauf, H. (1994). Identification of the ATP-binding site in tyrocidine synthetase I by selective modification with fluorescein $5^{\prime}$ isothiocyanate. J Biol Chem 269, 14962-14966.
Reichenbach, H. (1986). The myxobacteria: common organisms with uncommon behaviour. Microbiol Sci 3, 268-274.

Reichenbach, H., Gerth, K., Irschik, H., Kunze, B. \& Hofle, G. (1988). Myxobacteria: a source of new antibiotics. Trends Biotechnol 6, 115-121.

Rusnak, F., Sakaitani, M., Drueckhammer, D., Reichert, J. \& Walsh, C. T. (1991). Biosynthesis of the Escherichia coli siderophore enterobactin: sequence of the $e n t F$ gene, expression and purification of EntF, and analysis of covalent phosphopantetheine. Biochemistry 30, 2916-2927.

Sambrook, J, Fritsch, E. F. \& Maniatis, T. (1989). Molecular cloning: a laboratory manual. Cold Spring Harbor, NY: Cold Spring Harbor Laboratory.

Sanger, F., Nicklen, S. \& Coulson, A. R. (1977). DNA sequencing with chain terminating inhibitors. Proc Natl Acad Sci USA 74, 5463-5467.

Saulnier, P, Hanquier, J., Jaoua, S., Reichenbach, H. \& Guespin, M. J. (1988). Utilization of IncP-1 plasmids as vectors for transposon mutagenesis in myxobacteria. J Gen Microbiol 134, 2889-2895.

Schlumbohm, W., Stein, T., Ullrich, C., Vater, J., Krause, M., Marahiel, M. A., Kruft, V. \& Wittmann-Liebhold, B. (1991). An active serine is involved in covalent substrate amino acid binding at each reaction center of gramicidin S synthetase. J Biol Chem 266, 23135-23141.

Schupp, T., Toupet, C., Cluzel, B., Neff, S., Hill, S., Beck, J. J. \& Ligon, J. M. (1995). A Sorangium cellulosum (Myxobacterium) gene cluster for the biosynthesis of the macrolide antibiotic Soraphen A: cloning, characterization, and homology to polyketide synthases from Actinomycetes. J Bacteriol 177 (in press).

Simon, R., Priefer, U. \& Puhler, A. (1983). A broad host range mobilization system for in vivo genetic engineering: transposon mutagenesis in gram negative bacteria. Bio/Technology 1, 784-791.

Simon, R., O'Connell, M., Labes, M. \& Puhler, A. (1986). Plasmid vectors for the genetic analysis and manipulation of rhizobia and other Gram-negative bacteria. Methods Enzymol 118, 643-659.

Smith, D. J., Earl, A. J. \& Turner G. (1990). The multifunctional peptide synthetase performing the first steps in penicillin biosynthesis in Penicillium chrysogenum is a 421073 dalton protein similar to Bacillus brevis peptide antibiotic synthetases. EMBO J 9, 2743-2750.

Stein, T., Vater, J., Kruft, V., Wittmann-Liebold, B., Franke, P., Panico, M., Dowell, R. M. \& Morris, H. R. (1994). Detection of 4'phosphopantetheine at the thioester binding site for L-valine of gramicidin S synthetase 2. FEBS Lett 340, 39-44.

Tohika, K., Hori, K., Kurotzu, T., Kanda, M. \& Saito, Y. (1993). Effect of single base substitutions at glycine- 870 codon of gramicidin $S$ synthetase 2 gene on proline activation. $J$ Biochem 114, 522-527.

Tolchinsky, S., Fuchs, N., Varon, M. \& Rosenberg, E. (1992). Use of Tn5lac to study expression of genes required for production of the antibiotic TA. Antimicrob Agents Chemotber 36, 2322-2337.

Trowitzsch-Kienast, W., Irschick, H., Reichenbach, H., Wray, V. \& Höfle, G. (1988). Isolierung und Strukturaufklärung der Saframycine $\mathrm{Mx} 1$ und $\mathrm{Mx} 2$, neue antitumor-aktive Antibiotika aus Myxococcus xantbus. Liebigs Ann Chem 475-481.

Turgay, K., Krause, M. \& Marahiel, M. A. (1992). Four homologous domains in the primary structure of $\mathrm{GrsB}$ are related to domains in a superfamily of adenylate-forming enzymes. Mol Microbiol 6, 529-546.

Varon, M., Fuchs, N., Monosov, S., Tolchinsky, S. \& Rosenberg, E. (1992). Mutation and mapping of genes involved in production of 
the antibiotic TA in Myxococcus xanthus. Antimicrob Agents Chemother 36, 2316-2321.

Vollenbroich, D., Kluge, B., D'Souza, C., Zuber, P. \& Vater, J. (1993). Analysis of a mutant amino acid-activating domain of surfactin synthetase bearing a serine-to-alanine substitution at the site of carboxylthioester formation. FEBS Lett 325, 220-224.

Weckermann, R. W., Fürbaß, R. \& Marahiel, M. A. (1988).

Complete nucleotide sequence of the $\operatorname{tyc} A$ gene coding the tyrocidine I synthetase from Bacillus brevis. Nucleic Acids Res 16, 11841.

Weinred, S. M. , Basha, F. Z., Hibino, S., Khatri, N. A., Kim, K., Rye, W. E. \& Wu, T. T. (1982). Total synthesis of the antitumor antibiotic streptonigrin. J Am Cbem Soc 104, 536-544.

Received 4 April 1995; accepted 27 April 1995. 